\title{
PERANCANGAN KASULA DAN STOLA DENGAN IDE PENGGAMBARAN GORGA BATAK TOBA MELALUI TEKNIK BATIK TULIS
}

\author{
Hardianti Veronika Rajagukguk ${ }^{1}$ \\ (Jurusan Kriya Tekstil, Fakultas Seni Rupa Dan Desain, UNS Surakarta, hardiantiveronika@gmail.com, \\ veronikargg@student.uns.ac.id, +628134531979) \\ Theresia Widyastuti² \\ (Jurusan Kriya Tekstil, Fakultas Seni Rupa Dan Desain, UNS Surakarta, theresia.widiastuti@yahoo.co.id) \\ Felix Ari Dartono ${ }^{3}$ \\ (Jurusan Kriya Tekstil, Fakultas Seni Rupa Dan Desain, UNS Surakarta, devalois58@gmail.com)
}

\begin{abstract}
The background of the design of the chasuble and stole with the idea of the Toba Batak Gorga is the widest opportunity given by the Roman Chatolic Church based in Rome. The opportunity given is to decorate the Eucharistic ceremonial equipment with the characteristics of each region, without leaving the symbolism that has been determined. The study was conducted at the Saint Anthony of Padua Chatolic Church in Tiga Dolok North Sumatra. This design aims to make the latest innovations from the chasuble and stole from the aesthetic side. Using a design method that goes through visualization, the idea of symbolic drawing is taken from the typical ornaments of the Toba Batak tribe, namely Gorga dan completed with hand-drwan thecniques colored with synthetic dyes remasol. The result of this research is a cotton chasuble and stole, with a depiction of a Gorga that shows it's character in three colors: black, red and white, known as tiga bolit.
\end{abstract}

Keywords: Chasuble, Stole, Gorga, Hand-Drawn Batik

\begin{abstract}
ABSTRAK
Latar belakang perancangan kasula dan stola dengan ide penggambaran Gorga Batak Toba ini akibat terbukanya kesempatan seluas-luasnya yang diberikan oleh Gereja Katolik yang berpusat di Roma. Kesempatan yang diberikan yaitu untuk menghias perlengkapan Upacara Ekaristi dengan ciri khas daerah masing-masing tanpa meninggalkan simbol yang selama ini sudah ditentukan. Penelitian dilakukan di Gereja Katolik Santo Antonius Padua Tiga Dolok Sumatera utara. Perancangan ini bertujuan untuk membuat inovasi terbaru dari stola dan kasula dari sisi estetik. Menggunakan metode perancangan desain yang melalui tahap konsep hingga visualisasi, ide penggambaran simbol diambil dari ornamen khas suku Batak Toba, yakni Gorga dan diselesaikan dengan teknik batik tulis yang diwarnai dengan zat pewarna sintetis remasol. Hasil dari penelitian ini adalah berupa stola dan kasula berbahan katun, dengan penggambaran gorga yang menonjolkan karakternya berupa tiga macam warna: hitam, merah, dan putih yang dikenal sebagai tiga bolit.
\end{abstract}

Kata kunci: Kasula, Stola, Gorga, Batik Tulis 


\section{PENDAHULUAN}

Pakaian merupakan kebutuhan primer dalam kehidupan sehari-hari termasuk juga dalam upacara adat, serta menjadi kebutuhan dalam tata cara ibadat. Pakaian liturgi pelengkap yang dipakai oleh seorang Imam/Pastor, Diakon, Misdinar (putra-putri altar), dan Lektor dalam perayaan ekaristi. Stola dan kasula merupakan pakaian liturgi yang mempunyai fungsi yang sama dan wajib dipakai oleh seorang Imam/Pastor dalam perayaan Ekaristi.

Proyek ini merancang simbol pada pakaian liturgi yang disebut dengan kasula dan stola, khususnya yang selalu dikenakan oleh seorang Pastor/Imam ketika perayaan ekaristi dalam Gereja Katolik. Penggambaran simbolnya terinspirasi dari ornamen khas suku Batak Toba, yang dikenal sebagai Gorga dengan teknik pembuatan batik tulis.

Proses perancangan proyek Tugas Akhir ini dilandasi dengan suatu pokok permasalahan yaitu bagaimana merancang simbol-simbol pada kasula dan stola dengan ide penggambaran Gorga Batak serta menggunakan teknik batik tulis.

Tujuan utama perancangan ini untuk 1) memperbarui pengalaman Kristiani Gereja dan mengarahkan budaya Batak khususnya, agar tercipta kesatuan dan persekutuan antara budaya yang bersangkutan dengan pengalaman Kristiani melalui sebuah kasula dan stola. 2) mengingatkan akan budaya Batak khususnya kepada masyarakat Batak itu sendiri. Teknik batik tulis dalam kasula dan stola merupakan salah satu teknik yang masih sangat jarang ditemukan di Medan, Sumatera Utara.

\section{METODE}

Metode pengumpulan data dalam peracangan ini melalui beberapa metode yaitu observasi, wawancara, serta dokumentasi.
Observasi yang dilakukan yaitu bertempat di Gereja Santo Antonius Padua Tiga Dolok, Sumatera Utara. Hasil observasinya berdasarkan pengamatan secara langsung terhadap umat, dekorasi serta suasana, ketika melakukan ibadah sangat kental dengan suku Batak Toba.

Wawancara dilakukan untuk memperoleh informasi dan keterangan untuk mendukung peleitian. Jenis wawancara yang saya lakukan dalam penelitian ini adalah semi struktur, kemudian satu persatu ditanyakan kepada informan dan diperdalam lagi dengan membahas lebih jauh. Kegiatan wawancara dilakukan bersama beberapa Pastor/Imam yang lebih menguasai tentang kasula dan stola, serta terhadap pengrajin batik.

Dokumentasi dilakukan di tempat penelitian, berdasarkan peristiwa yang penulis lihat. Proses dokumentasinya melalui foto-foto, rekaman wawancara, dan buku-buku yang digunakan untuk mengumpulkan data yang dibutuhkan.

Metode-metode diatas akan dijelaskan secara rinci dalam analisis permasalahan dan strategi pemecahan masalah.

\section{a. Analisis Permasalahan}

Gorga merupakan suatu pesan hasrat dan nasehat yang bersumber dari pengetahuan, harapan, buah pikiran, sikap perilaku, dan keindahan yang hendak dikomunikasikan. Ragam hias Gorga adalah macam-macam pola hiasan yang dibuat untuk memperindah rumah adat (eksterior rumah), yang diwariskan turuntemurun melatarbelakangi pola pikir masyarakat suku Batak Toba. Perancangan teknik batik tulis pada kasula dan stola dengan cara penggambaran Gorga, memiliki beberapa permasalahan. Beberapa permasalahan yang harus diselesaikan dalam proyek perancangan 
ini, antara lain: visual yang menampilkan kekhasan Gorga, simbol yang sering ditemui pada kasula dan stola, dan desain batik yang dapat di produksi oleh pengrajin batik tulis.

Produk yang dihasilkan dari perancangan ini diharapkan dapat menampilkan visual yang khas dan indah, terutama penggambarannya dapat dikenali oleh masyarakat Batak Toba sendiri. Proyek perancangan ini harus sesuai dengan kebutuhan dalam Gereja Katolik baik dari segi warna maupun simbol-simbol pada pakaian liturgi, serta menghasilkan inovasi baru karena pada umumnya kasula dan stola kebanyakan dibuat dengan teknik sulam dan border. Perancangan proyek ini dibuat dengan teknik batik tulis serta menggunakan zat pewarna sintetis.

Visual dari batik yang akan diproduksi pengrajin juga harus dipertimbangkan dari segi warna, ukuran, kerumitan desain serta kain yang akan digunakan. Kasula dan stola ini akan dipakai oleh seorang Imam/Pastor dalam Upacara Ibadat sehingga, pemilihan bahan juga perlu untuk dipertimbangkan demi kenyamanan Imam yang menggunakan kasula dan stola.

\section{b. Strategi Pemecahan Masalah}

Dibutuhkan strategi pemecahan yang tepat agar beberapa permasalahan dalam perancangan dapat diselesaikan dengan efektif dan efisien. Metode pengumpulan data yang dilakukan adalah melalui studi lapangan, wawancara, dan dari berbagai pustaka terkait. Strategi yang dilakukan untuk menghasilkan rancangan dengan menampilkan visual yang khas, dilakukan berdasarkan pengumpulan data melalui studi lapangan. Studi lapangan merupakan salah satu metode pengumpulan data yang bertujuan untuk mendapatkan data berdasarkan peristiwa yang terjadi.
Kegiatan wawancara dilakukan dengan beberapa Pastor/Imam, agar produk yang dihasilkan sesuai dengan liturgi dalam Gereja Katolik. Wawancara dilakukan untuk memperkuat data dan memperoleh keterangan-keterangan yang berkaitan dengan proses perancangan proyek. Beberapa strategi juga telah dilakukan seperti studi mengenai teknik dan wawancara dengan pengrajin batik tulis. Hal untuk mengetahui kemampuan teknis dalam pembuatan batik agar produk produk yang dirancang dapat dikerjakan dengan baik oleh pengrajin.

\section{PEMBAHASAN DAN HASIL}

\section{a. Kasula dan Stola}

Pakaian liturgi adalah pakaian yang dipakai untuk upacara peribadatan, termasuk juga upacara Ekaristi. Uskup, Pastor/Imam, Misdinar, maupun petugas liturgi lainnya mengenakan pakaian peribadatan (Whindu, 1997: 13). Kasula merupakan pakaian misa paling luar yang dikenakan Imam, yang dipakai untuk memimpin perayaan Ekaristi. Kasula melambangkan keutamaan cinta kasih dan ketulusan untuk melaksanakan tugas yang penuh pengorbanan diri bagi Tuhan. (Lukefahr dan Shakti, 2014: 111). Stola adalah semacam selempang atau selendang dari kain halus yang dikenakan pada bahu turun ke dada. (Whindu, 1997: 18). Stola memiliki simbol bahwa yang mengenakan sedang melaksanakan tugas resmi Gereja, terutama menyangkut tugas pengudusan (Imamat). Stola melambangkan otoritas atau kewenangan dalam pelayanan sakramental dan berkhotbah (Lukefahr dan Shakti, 2014: 110).

Tujuan penggunaan busana liturgi adalah untuk menunjukkan bahwa Imam hadir bukan atas otoritasnya sendiri, tetapi sebagai seorang pelayan Kristus. Keindahan busana 
liturgi mendorong hati dan pikiran kita untuk lebih tertuju kepada Allah dan warna-warni busana liturgi memiliki hakikat spiritual (Lukefahr dan Shakti, 2014: 111). Gereja Katolik mempunyai pemahaman norma tersendiri dan baku akan warna, karena setiap warna merefleksikan nilai dan makna rohani tertentu. Pemakaian warna tersebut, disesuaikan dengan masa dan perayaan atau pesta tertentu menurut penaggalan kalender liturgi yang dikenakan oleh Prodiakon, Lektor/Lektris dan Putra/Putri Altar. Jenis warna yang digunakan dalam warna liturgi yaitu putih atau kuning (makna kehidupan baru, dipakai saat Masa Paskah, Natal, perayaan-perayaan Tuhan Yesus (kecuali peringatan sengsara-Nya), serta peringatan Santa dan Santo pelindung), merah (makna api dan darah, dipakai saat hari Minggu Palma, Jumat Agung, Minggu Pentakosta, perayaan Sengsara Tuhan, pesta para rasul dan pengarang Injil (kecuali Yohanes), serta perayaan para martir), hijau (tenang, menyegarkan, melegakan, dan manusiawi, dipakai saat Masa Biasa sepanjang tahun), dan ungu (simbol kebijaksanaan, keseimbangan, sikap berhati-hati, dan mawas diri, digunakan saat masa Adven dan Prapaskah).

\section{b.Gorga}

Indonesia memiliki keanekaragaman budaya yang sangat luar biasa. Semua budaya tradisi memiliki nilai dan kedudukan yang sangat penting bagi masyarakat Indonesia karena budaya tradisi mengajarkan bersyukur, mengajarkan saling menghormati, dan lain sebagainya. Melalui budaya akan semakin arif dan bijak dalam kehidupan. Budaya yang ada di Indonesia mengandung makna kearifan lokal bagi masyarakt di wilayah asal budaya itu di kenal (Panjaitan dan Sundawa, 2016: 65).
Gorga juga menjadi salah satu ornamen yang memiliki filosofi yang mendalam. Seperti yang sudah di jelaskan diatas, bahwa Gorga merupakan suatu pesan hasrat dan nasehat yang bersumber dari pengetahuan, harapan, buah pikiran, sikap perilaku, dan keindahan yang hendak dikomunikasikan. Ragam hias Gorga adalah macam-macam pola hiasan yang dibuat untuk memperindah rumah adat (eksterior rumah), yang diwariskan turuntemurun melatarbelakangi pola pikir masyarakat suku Batak Toba. Gorga memiliki tiga warna sebagai ciri khas serta tiga garis yang disebut sebagai Gorga si tolu lili (Gorga dengan tiga garis), dan terkadang sampai memiliki lima garis atau disebut Gorga si lima lili (Gorga dengan lima garis). Ketiga warna itu adalah hitam (makna kekuatan), merah (makna keberanian) dan putih (makna kesucian). Beberapa jenis Gorga yang biasanya ditemukan dalam suku Batak Toba yaitu sebagai berikut: Gorga simeol-meol Marsiaolan merupakan suatu deformasi dari gerak tumbuhan lumut yang melenggang-lenggok dengan arah lengkungan masuk kedalam dan keluar (Panggabean dan Lestari, 2015: 685).

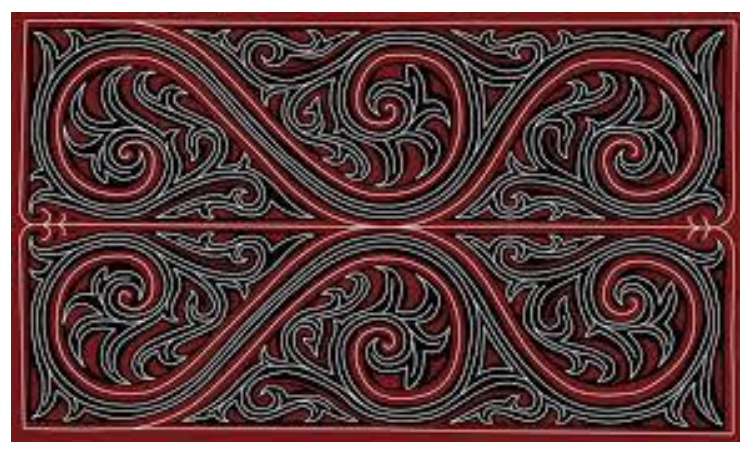

Gambar 1 : Gorga Simeol-meol Marsiaolan Sumber : Foto Google

Gorga Sitompi adalah motif Gorga yang mengambil bentuk tompi (ketaya: anyaman rotan yang dipergunakan untuk mengikat leher kerbau) sebagai pola dasar bentuknya yang 
menggambarkan ikatan kekeluargaan yang saling jalin-menjalin.

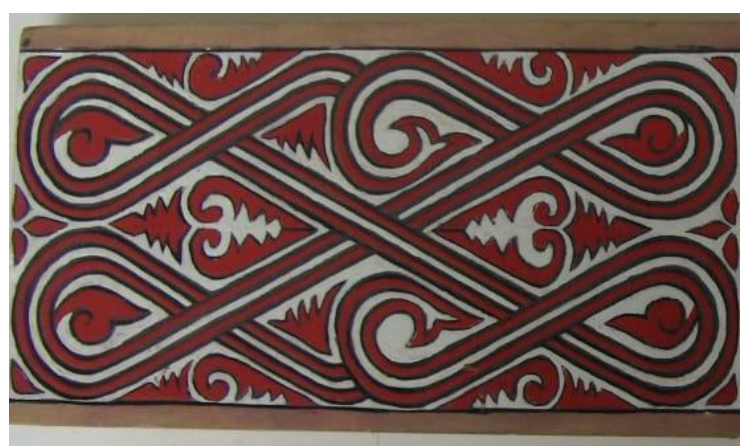

Gambar 2 : Gorga Sitompi

Sumber : Foto Google

Gorga Bindu Matoga adalah diagram perputaran Pane $\mathrm{Na}$ Bolon (sejenis naga raksasa) atau Naga Padoha. Garis lintasan Pane $\mathrm{Na}$ Bolon inilah yang menjadi dasar bentuk Gorga Bindu Matoga yaitu empat induk desa dan empat anak mata angin utama Gorga Matoga yang dilambangkan sebagai titik pusat yang berdaya kuasa.

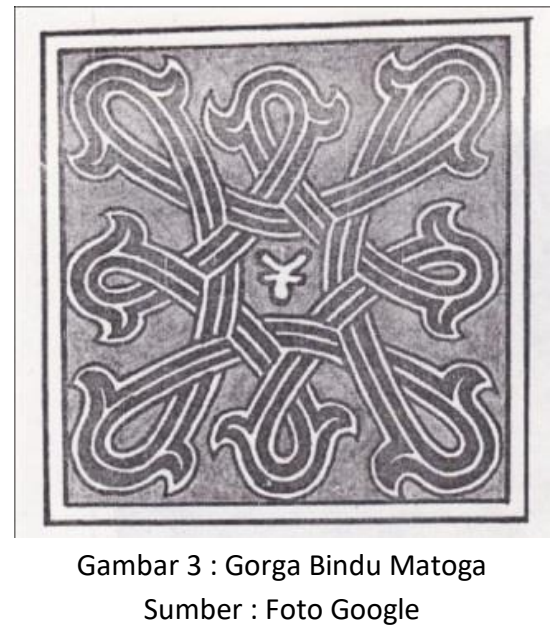

Gorga Boraspati dibuat seperti bentuk seekor cicak serta badan berloreng-loreng. Gorga Boraspati melambangkan kekuatan pelindung manusia dari bahaya, yang dilambangkan dengan Dewa Alam. Penggambaran Gorga ini dipercaya sebagai pelindung harta kekayaan serta mengharapkan kekayaan yang berlipat ganda.

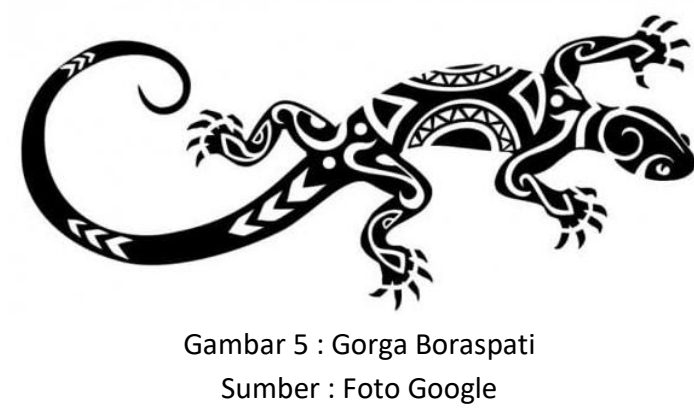

Gorga Dalihan Na Tolu berbentuk menyerupai jalinan sulur tumbuhan yang saling kaitmengkait yang melambangkan kekerabatan. Dalihan Na Tolu adalah pandangan hidup dalam masyarakat Batak yang memiliki nilai-nilai yang bersifat universal. Dalihan $\mathrm{Na}$ Tolu terbagi menjadi tiga kedudukan fungsional di dalam masyarakat Batak yaitu, Somba Marhula-hula (hormat kepada keluarga dari pihak istri), Elek Marboru (mengayomi wanita), dan Manat Mardongan Tubu (bersikap sopan/hati-hati kepada teman semarga). Tiga kedudukan yang menjadi penyokong adat inilah yang disimbolisasikan ke dalam bentuk visual Dalihan $\mathrm{Na}$ Tolu (tungku berkaki tiga). Tungku yang memiliki tiga kaki, memiliki keseimbangan yang mutlak, karena tungku tersebut tidak berdiri dan tidak dapat digunakan apabila salah satu kakinya rusak. Berdasarkan makna tersebut, leluhur suku Batak memilih tungku berkaki tiga sebagai falsafah hidup dalam tatanan kekerabatan antara sesama yang bersaudara atau satu marga dengan kelompok pemberi istri dan kelompok penerima istri. Segala kegiatan adat masyarakat Batak tidak dapat berjalan dan terlaksana apabila salah satu dari ketiga unsur tersebut tidak ada (Tampubolon, 2017: 499). 


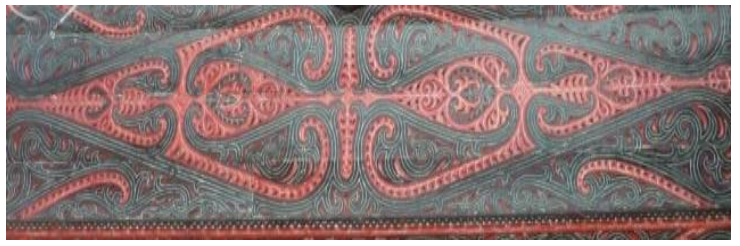

Gambar 4 : Gorga Dalihan Na Tolu Sumber : Foto Google

Gorga Desa Na Ualu adalah Gorga yang menggambarkan kedelapan mata angin. Gorga ini dibuat sebagai simbol perbintangan yaitu sebagai alat peramal untuk menentukan saatsaat yang baik untuk menanam padi, menangkap ikan, mengadakan pesta, dan lain sebagainya.

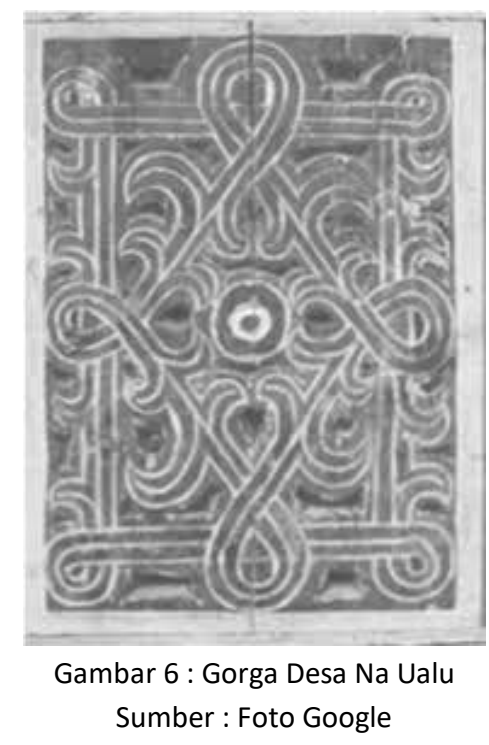

\section{c. Batik Tulis}

Batik adalah salah satu teknik tekstil dengan cara menutup permukaan kain sebelum diwarnai atau dikenal sebagai teknik tutup celup (resist and dye). Bahan perintangnya menggunakan malam/lilin. Teknik ini sebenarnya adalah sebuah teknik kuno yang sudah ada semenjak ribuan tahun lalu dan dapat dijumpai di seluruh peradaban dunia (Ramadhan, 2013: 13).

Beberapa negara, medium yang digunakan untuk merintang atau menahan warna berbeda-beda. Ada yang menggunakan bubur kanji, bahkan ada yang menggunakan bubur nasi yang dikeringkan. Indonesia menggunakan malam/lilin sebagai bahan perintang lalu di torehkan keatas permukaan kain mori. Inilah salah satu hal yang membedakan batik Indonesia dengan batik di belahan bumi lainnya yang membuat motif batik kita begitu kaya akan detail (Ramadhan, 2013: 14).

Batik tulis dikerjakan dengan menggunakan canting. Canting merupakan sebentuk alat tulis dari Jawa yang terbuat dari logam dengan tangkai bambu atau kayu, yang digunakan untuk menggoreskan malam panas pada permukaan kain. Canting diakui sebagai alat yang lahir dari kearifan lokal asli Indonesia, bagian dari tradisi seni batik sebagai warisan (Yudhoyono, 2013: 99).

\section{d. Pengumpulan Data}

Pengumpulan data telah dilakukan melalui kegiatan wawancara dengan beberapa Pastor yaitu, Pastor Emmanuel Sembiring OFMCap, Pastor Gindo G. Saragih OFMConv, dan Pastor Rufinus Ero Jenska Peranginangin OFMConv, serta wawancara terhadap pengrajin batik tulis di Kampung Batik, Laweyan. Data yang telah dikumpulkan adalah berupa inkulturasi budaya Batak dalam perayaan ekaristi pada Gereja Katolik Santo Antonius Padua Tiga Dolok, jenis simbol dan teknik dalam pakaian liturgi pada umumnya, jenis bahan, warna dan ukuran.

Menurut hasil wawancara yang telah dilakukan dengan beberapa Imam/Pastor, pada umumnya salib merupakan simbol utama yang menghiasi busana liturgi. Simbol-simbol lainnya yang menghiasi busana liturgi adalah roti dan anggur, gandum, alpa dan omega, ikan, XP, IHS, lilin, anak domba, piala anggur, dll. Simbolsimbol yang dibuat berasal dari kitab suci. Hasil 
dokumentasi yang dilakukan, mendapatkan beberapa jenis kasula dan stola yang dipakai para Pastor/Imam dengan desain simbol yang berbeda serta dibuat dengan teknik border, berikut hasil dokumentasinya:
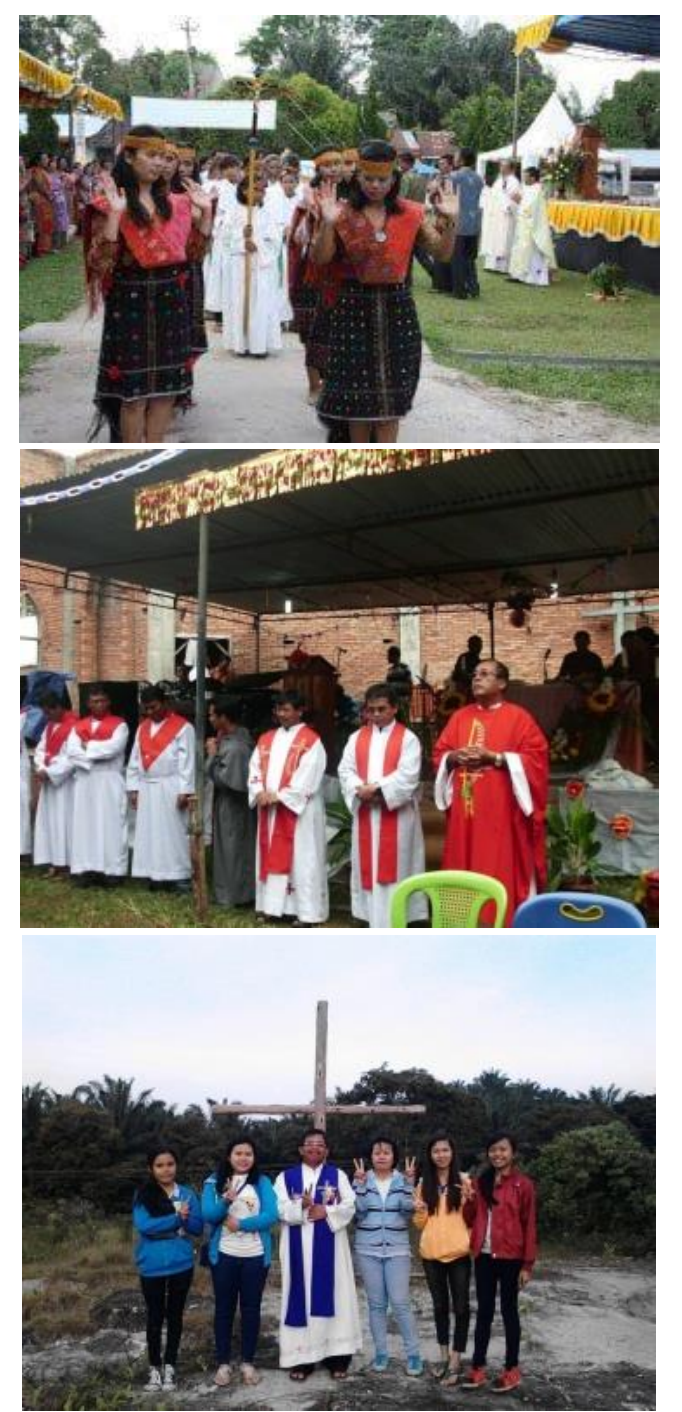

Gambar 8 : Hasil dokumentasi kasula, stola serta suasana saat studi lapangan

Foto : Hardianti Veronika Rajagukguk 2019

Di Gereja Katolik Santo Antonius Padua Tiga Dolok, terdapat unsur budaya Batak sebagai bagian yang mendukung saat perayaan ekaristi, mulai dari bahasa yang digunakan, tarian khas Batak saat perarakan, hingga proses dekorasi menggunakan ulos. Perancangan simbol pada kasula dan stola adalah berbentuk salib, roti dan anggur, gandum, ikan, anak domba, lilin, alpa dan omega, piala, dan tulisan aksara Batak Toba. Perancangan simbol pada kasula dan stola didesain dengan ide penggambaran Gorga yang diartikan sebagai salah satu cari khas dari suku Batak Toba dalam berkomunikasi lewat simbol. Perancangan simbol dengan khas Batak akan menjadi kesatuan yang selaras jika diterapkan dalam Gereja tersebut. Pemilihan teknik batik tulis juga merupakan inovasi baru serta menjadi salah satu alternatif lain dalam perancangan kasula dan stola untuk Gereja tersebut. Tektik yang umumnya digunakan dalm pembuatan simbol pada kasula dan stola, yaitu menggunakan teknik border dan sulam.

Pemilihan bahan adalah salah satu unsur yang penting dilakukan serta dipertimbangkan dan disesuaikan dengan kondisi daerah setempat. Jenis bahan kain yang akan digunakan dalam proyek perancangan ini adalah kain katun Bercolin yang merupakan salah satu jenis kain tidak terlalu panas, serta dapat menyerap keringat dengan maksimal ketika dipakai. Pemilihan kain katun Bercolin diharapkan dapat menampilkan kesan sederhana seperti Yesus yang berpenampilan sederhana. Pada umumnya pakaian liturgi terbuat dari kain dengan bahan yang berbedabeda, salah satunya sutra. Berbanding terbalik dengan katun, bahwa kain sutra merupakan salah satu bahan yang memberi kesan mewah, mengkilap, dan mahal. Tidak ada ketentuan ukuran khusus dalam ukuran kasula dan stola, karena tinggi dari Imam/Pastor berbeda-beda baik dari dalam maupun luar negeri. Perancangan kasula dan stola yang dirancang dengan ukuran yang tidak jauh berbeda dari umumnya. Warna kasula dan stola yang akan dirancang disesuaikan dengan warna liturgi 
yang berlaku yaitu putih/kuning, merah, hijau, dan ungu.

\section{e. Konsep Perancangan}

Konsep perancangan ini adalah merancang simbol pada kasula dan stola sebagai pakaian liturgi yang ide penggambarannya memberi kesan visual khas dari Gorga dengan menggunakan teknik batik tulis. Perancangan ini dimulai dengan memahami karakter dari sumber ide yang dipilih yaitu Gorga kemudian dikembangkan menjadi bentuk simbol-simbol dalam Gereja Katolik. Karakter dari Gorga biasanya memiliki 3 macam warna yaitu hitam merah, dan putih yang disebut dengan tiga bolit, serta memiliki 3 garis sebagai warna putih.

Simbol-simbol yang akan dirancang pada kasula dan stola adalah berbentuk salib, roti dan anggur, gandum, ikan, anak domba, lilin, alpa dan omega, piala, dan tulisan aksara Batak Toba. Perancangan kasula dan stola ini menggunakan teknik batik tulis yang dapat memunculkan inovasi baru serta menghasilkan visual yang berbeda dan ekspresif. Penggunaan warna sintetis yang dilakukan adalah melalui pewarnaan zat warna remasol.

Ide dalam sebuah perancangan, mempertimbangkan beberapa aspek desain yang mendukung perancangan ini yaitu: aspek estetika, aspek material, aspek teknik, aspek fungsi. Melalui aspek-aspek tersebut, perancangan ini akan lebih terarah serta karya yang diciptakan menghasilkan sesuatu yang memiliki "nilai lebih" dibandingkan dengan produk sebelumnya. Tersirat adanya suatu usaha untuk memperbaiki, menyempurnakan atau mengembangkan sesuatu yang telah ada bahkan merancang atau menciptakan produk baru (Rizali, 2012 : 1). Aspek-aspek tersebut adalah sebagai berikut:

\section{Aspek Estetis}

Perancangan simbol didesain seperti ornamen Gorga dengan menerapkan karakter dari Gorga yaitu tiga garis serta memiliki tiga warna khas yaitu merah, putih, dan hitam, sehingga warna-warna desain pada kasula dan stola akan disesuaikan dengan warna-warna pada khas Gorga. Warna merupakan salah satu aspek yang sangat mendukung dalam perancangan visual desain yang estetis. Warna harus dapat mengesankan keselarasan (harmoni) antar bagian dan karakteristik produk. Selain sebagai salah satu fungsi estetik, warna juga dapat membantu dalam pengungkapan emosi tertentu (Rizali, 2006 : 21). Peletakan simbol pada kasula ditata secara rapi dan teratur yang dibagi menjadi dua bagian yaitu sisi depan dan belakang yaitu di bagian dada, punggung, dan ada motif pendukung pada bagian pinggir kasula. Peletakan simbol pada stola diaplikasikan di bagian bawah ujung, tengah, dan di dekat bahu. Susunan visual dari perancangan simbol memperhatikan bentuk, serta warna desain. Perancangan simbol dan warna ini juga harus memperhatikan warna dasar dari kasula dan stola yaitu putih/kuning, merah, hijau, dan ungu. Berdasarkan pertimbangan tersebut, maka akan menghasilkan warna yang menyatu dan harmonis dengan warna dasar dari kasula dan stola. Perancangan desain ini juga harus memperhatikan bentuk visual dari masingmasing simbol, mulai dari komposisi, warna, dan ukuran, sehingga setiap desain tidak mendominasi serta memiliki porsi masingmasing dalam tampilan visualnya. Masingmasing simbol dirancang untuk melengkapi dan berkaitan satu sama lain serta disesuaikan dengan simbol-simbol berdasarkan masa liturgi. 2. Aspek Teknik 
Aspek teknik merupakan salah satu tahap yang dilakukan dalam perancangan desain menjadi sebuah produk yang nyata. Teknik yang dilakukan dalam proyek perancangan kasula dan stola ini menggunakan teknik batik tulis yang pengerjaannya dilakukan di Kampung Batik, Laweyan. Proses membatiknya membutuhkan waktu kurang lebih 2 minggu, mulai dari penggambaran pola desain pada kain, proses pembatikan, pewarnaan, hingga pelorodan (proses menghilangkan malam dengan cara direbus). Pemilihan teknik ini berdasarkan survei lapangan yang sudah dilakukan di Gereja Katolik Santo Antonius Padua, Tiga Dolok, bahwa perancangan kasula dan stola masih menggunakan teknik sulam dan border. Harapan kedepannya semoga proyek ini dapat menghasilkan inovasi baru serta dapat digunakan oleh Imam/Pastor dalam perayaan ekaristi.

\section{Aspek Fungsi}

Perancangan proyek ini difungsikan sebagai pakaian liturgi dalam Gereja Katolik yang biasanya dipakai oleh Imam/Pastor dalam perayaan ekaristi, maupun tata cara ibadat lainnya. Perancangan yang dilakukan juga disesuaikan dengan penerapan warna liturgi yang sudah ditetapkan dalam Gereja Katolik, dan simbol-simbol yang biasanya ditampilkan dalam pakaian liturgi.

\section{Aspek Bahan}

Pemilihan bahan merupakan salah satu aspek yang penting untuk diperhatikan, sebab bahan sangat mempengaruhi kenyaman saat pemakaiannya. Bahan yang digunakan adalah katun Bercolin. Berdasarkan sifatnya, katun adalah salah satu jenis kain yang tidak terlalu panas, serta dapat menyerap keringat dengan maksimal ketika dipakai. Pemilihan kain katun Bercolin diharapkan dapat menampilkan kesan sederhana seperti Yesus yang berpenampilan sederhana. Pada umumnya pakaian liturgi terbuat dari kain dengan bahan yang berbedabeda, salah satunya sutra. Pemilihan bahan ini juga memperhatikan beberapa hal yang dipertimbangkan seperti iklim di Indonesia yaitu tropis, sehingga sebaiknya tidak menggunakan bahan yang tebal dan panas.

\section{f. Visualiasi}

Dari studi yang telah dilakukan, perancangan ini menghasilkan beberapa visual dengan jumlah 8 desain yaitu 4 kasula dan 4 stola. Total dari 8 jumlah desain tersebut, 6 diantaranya divisualkan dengan wujud tekstil dengan menggunakan teknik batik tulis, diwarnai dengan zat pewarna remasol yang diaplikasikan pada bahan katun Bercolin. 1 lembar kain berukuran $200 \mathrm{~cm} \times 120 \mathrm{~cm}$ dapat menghasilkan 1 stola dan 1 kasula. Total jumlah kain yang dibutuhkan untuk menghasilkan 3 stola dan 3 kasula berjumlah 3 lembar.

Pemilihan warna dalam perancangan ini mengikuti warna-warna liturgi yang terdapat dalam Gereja Katolik yaitu putih/kuning, merah, hijau, dan ungu. Kasula dan stola yang akan direalisasikan ke dalam sebuah produk adalah, warna merah (1 kasula dan 1 stola), hijau (1 kasula dan 1 stola), dan ungu (1 kasula dan 1 stola). Ide perancangan simbolnya terinspirasi dari ornamen Gorga suku Batak Toba yang berasal dari Medan, Sumatera Utara. Umumnya Gorga Batak di aplikasikan pada Eksterior di rumah adat. Berdasarkan studi lapangan dan data-data yang telah dihasilkan, maka proyek ini akan menghasilkan inovasi baru, melalui penggambaran simbol yang telah didesain. 


\section{Desain Kasula Kuning}

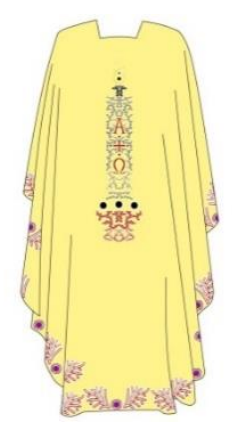

Gambar 9 : Desain kasula kuning bagian depan
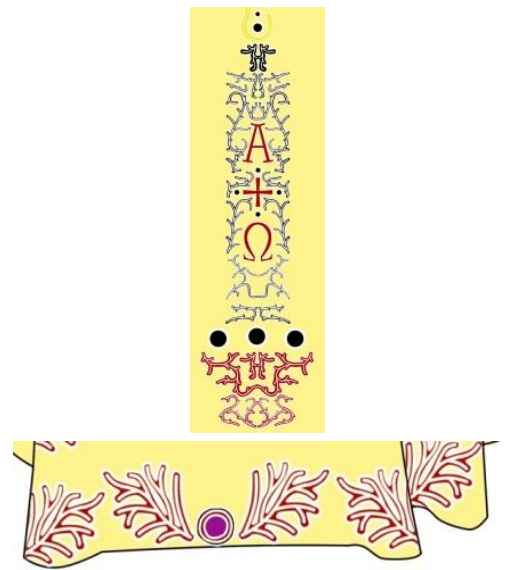

Gambar 10 : Detail Desain kasula kuning bagian depan

Desain ini terinspirasi dari simbol lilin paskah yang dialamnya terdapat simbol Alpa dan Omega, serta daun anggur sebagai motif penghias. Makna dari lilin paskah menyimbolkan kehidupan yang baru yang menyala. Api adalah lambang semangat yang berkobar-kobar. Ukuran desain $170 \mathrm{~cm}$ x 120 $\mathrm{cm}$.

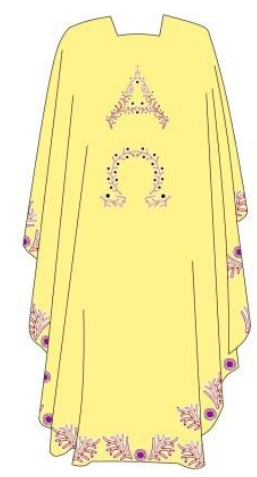

Gambar 11 : Desain kasula kuning bagian belakang

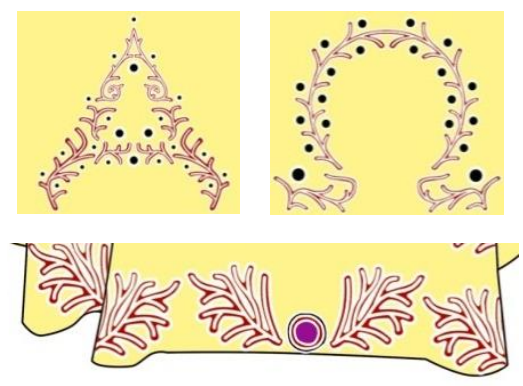

Gambar 12 : Detail desain kasula kuning bagian belakang

Desain ini distrukturkan dari simbol Alpa dan Omega, serta daun anggur sebagai motif penghiasnya. Alpa dan Omega huruf pertama dan terakhir alphabet Yunani dan simbolnya diartikan sebagai kekekalan Allah dan kuasa Kristus dari penciptaan sampai pada akhirat. Ukuran desain $180 \mathrm{~cm} \times 120 \mathrm{~cm}$.

\section{Desain Stola Kuning}

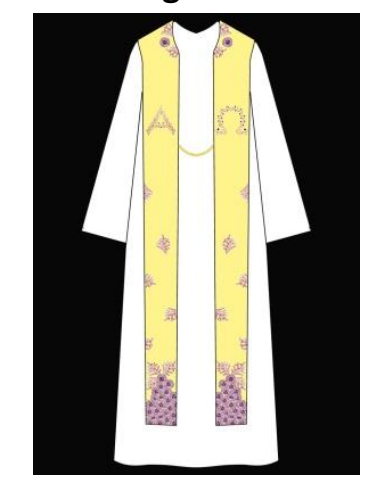

Gambar 13 : Desain stola kuning

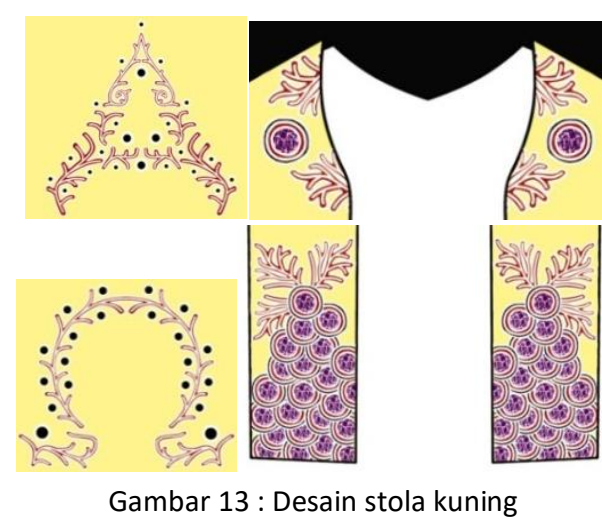

Desain ini distrukturkan dari simbol Alpa dan Omega, serta anggur. Alpa dan Omega 
adalah huruf pertama dan terakhir alphabet Yunani dan simbolnya diartikan sebagai kekekalan Allah dan kuasa Kristus dari penciptaan sampai pada akhirat. Arti warna kuning pada pakaian liturgi diartikan sebagai kehidupan baru. Ukuran stola $120 \mathrm{~cm} \times 18 \mathrm{~cm}$.

\section{Desain Kasula Merah}
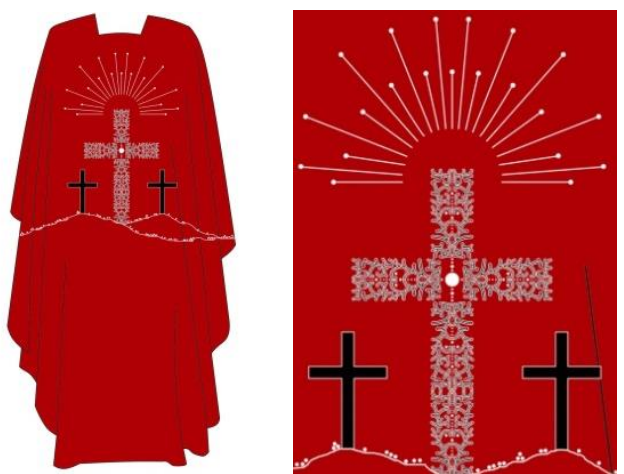

Gambar 14 : Desain kasula merah bagian depan Gambar 15 : Detail desain kasula merah bagian depan

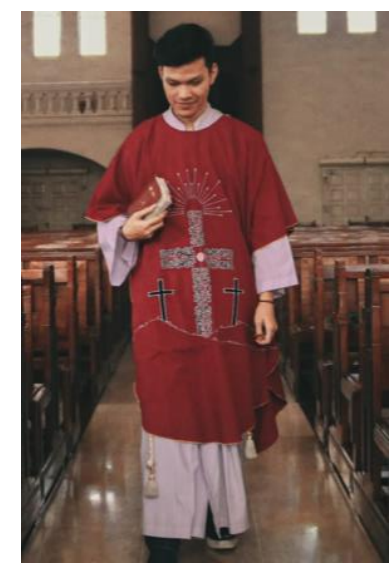

Gambar 16 : Foto produk kasula merah bagian depan

Foto: Hardianti Veronika Rajagukguk 2019

Desain ini distrukturkan dari simbol 3 salib di bukit. Desain ini menggambarkan ketika Yesus disalibkan di bukit Golgota dan la bersama dua orang juga disalibkan, satu disebalah kanan dan satu lagi disebelah kiriNya. Salib adalah simbol yang paling dikenal sebagai simbol kristiani. Ukuran desain $170 \mathrm{~cm}$ $x 120 \mathrm{~cm}$.

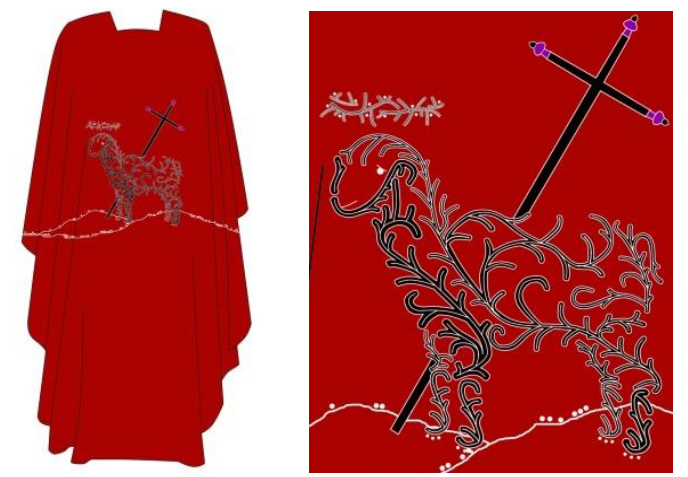

Gambar 17 : Desain kasula merah bagian belakang Gambar 18 : Detail desain kasula merah bagian belakang

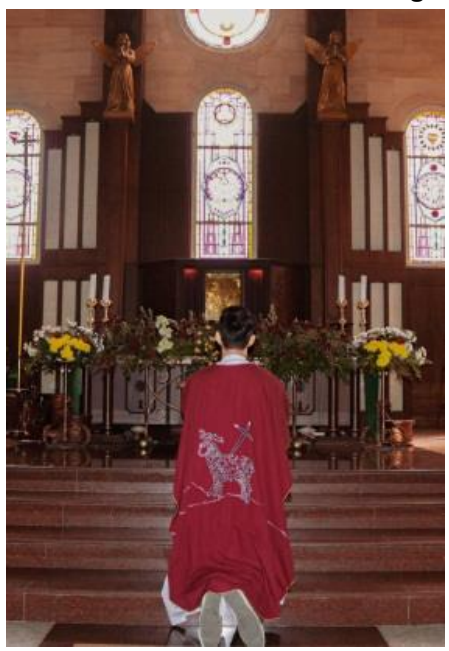

Gambar 19 : Foto produk kasula merah bagian belakang Foto: Hardianti Veronika Rajagukguk 2019

Desain ini distrukturkan dari simbol anak domba memakai mahkota duri dan salib dibelakangnya. Simbol domba diartikan sebagai lambang Yesus yaitu Anak Domba Allah. Ukuran desain $180 \mathrm{~cm} \times 120 \mathrm{~cm}$.

\section{Desain Stola Merah}

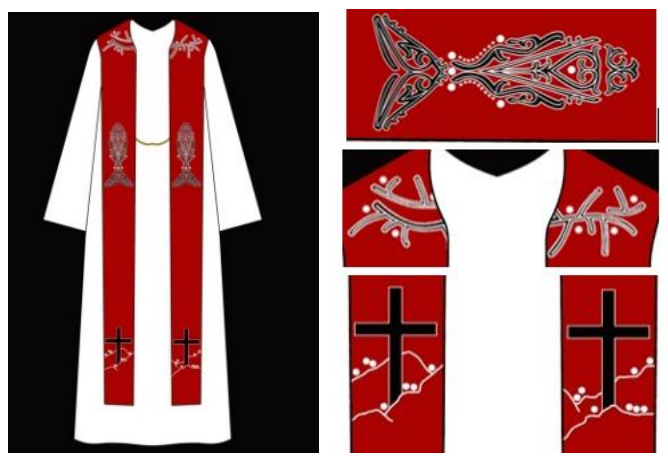

Gambar 20 : Desain stola merah

Gambar 21 : Detail desain stola merah 


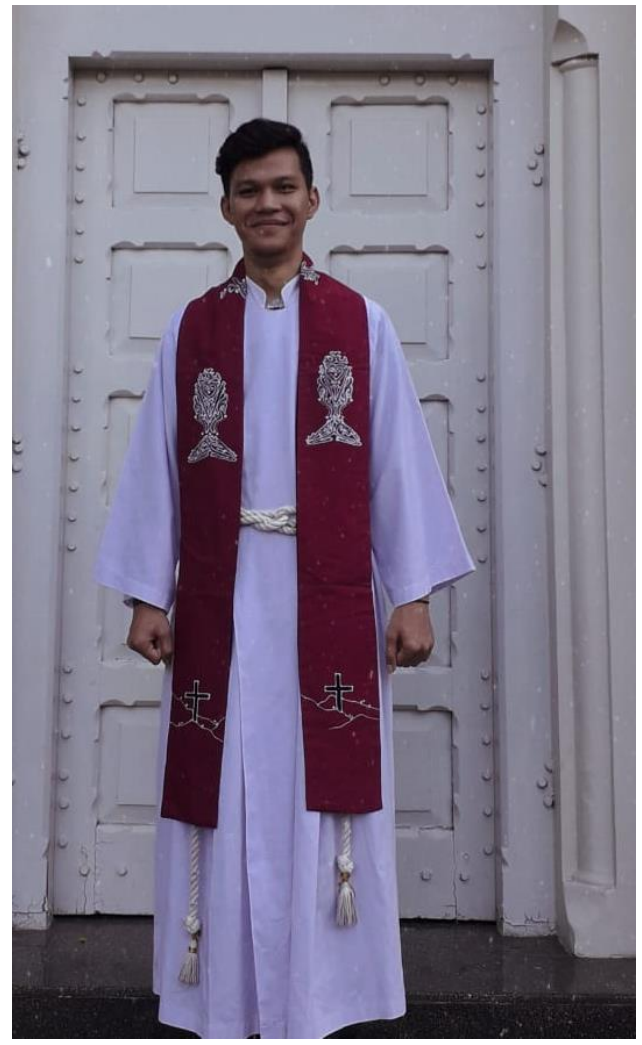

Gambar 22 : Foto Produk stola merah Foto: Hardianti Veronika Rajagukguk 2019

Desain ini distrukturkan dari simbol mahkota duri, ikan, dan salib di bukit. Mahkota duri dikenakan Yesus ketika la disalibkan di bukit Golgota. Salib di bukit mengingatkan akan peristiwa Yesus yang disalibkan di bukit Golgota. Ukuran desain $120 \mathrm{~cm}$ x $18 \mathrm{~cm}$.

\section{Desain Kasula Hijau}
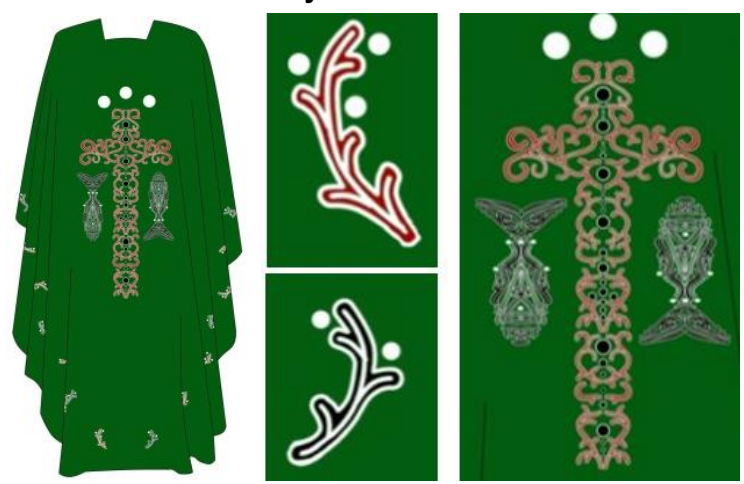

Gambar 23 : Desain kasula hijau bagian depan Gambar 24 : Detai desain kasula hijau bagian depan

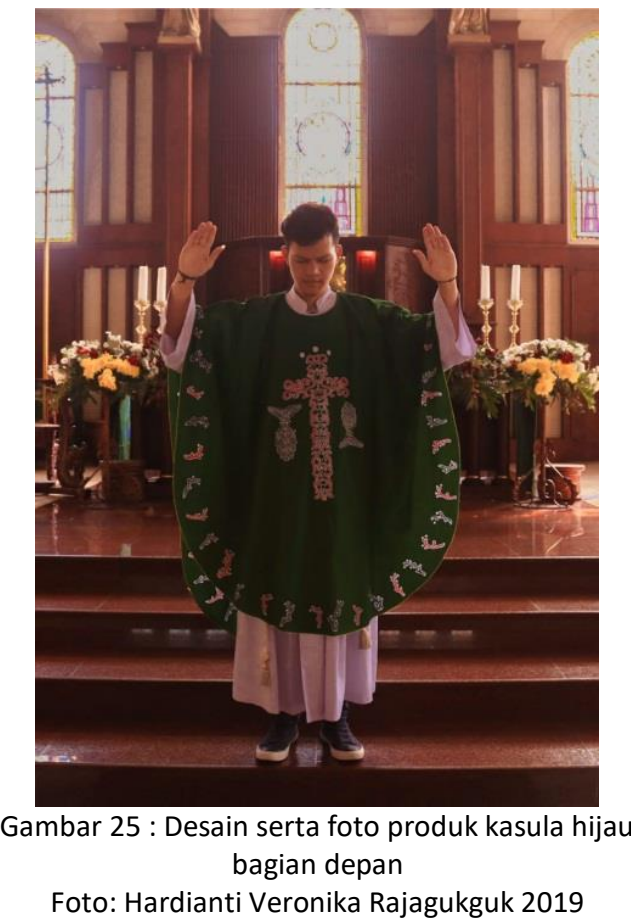

Desain ini distrukturkan dari salib sebagai simbol utama dan 2 ikan di sebelah kanan dan kiri dari salib. Salib adalah simbol yang paling dikenal sebagai simbol kristiani. Makna simbolik dari ikan dijadikan sebagai lambang Kristus yang berarti penyelamat, karena pada jaman dahulu dipercaya bahwa ikan adalah hewan yang dapat menjauhkan dari kejahatan. Ukuran desain $170 \mathrm{~cm} \times 120 \mathrm{~cm}$.

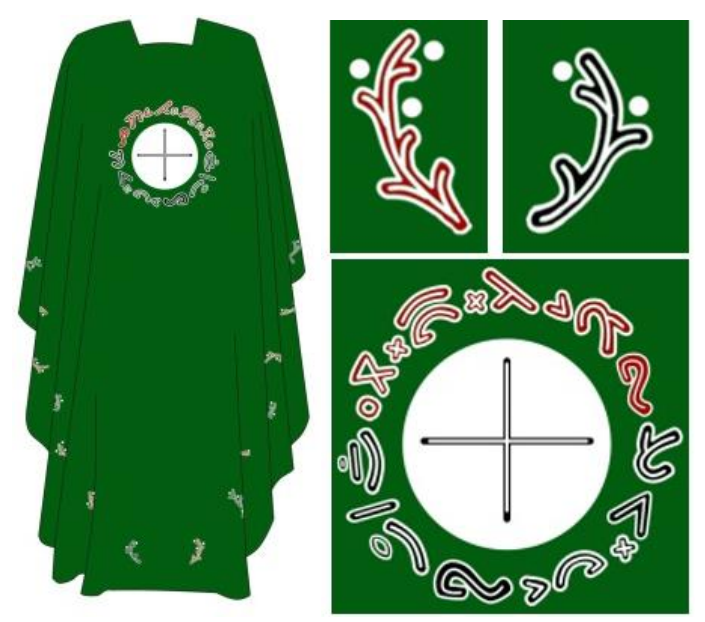

Gambar 26 : Desain kasula hijau bagian belakang Gambar 27 : Detai desain kasula hijau bagian belakang 
Desain ini distrukturkan dari simbol hosti yang biasanya saat perayaan ekaristi diberi kepada umat. Disekeliling dari hosti terdapat tulisan aksara Batak Toba yang jika dibaca "Ahu do Roti Hangoluani" yang berarti "Akulah roti kehidupan”. Ukuran desain $180 \mathrm{~cm} \times 120 \mathrm{~cm}$.

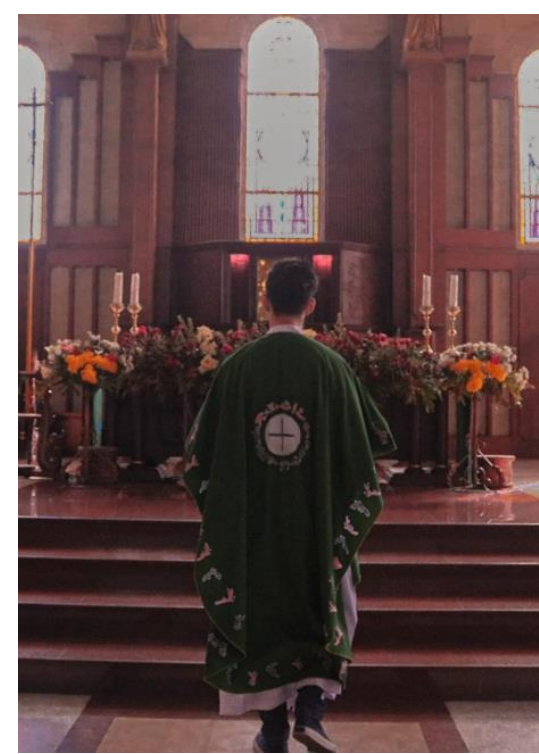

Gambar 28 : Foto produk kasula hijau bagian belakang Foto: Hardianti Veronika Rajagukguk 2019

\section{Desain Stola Hijau}

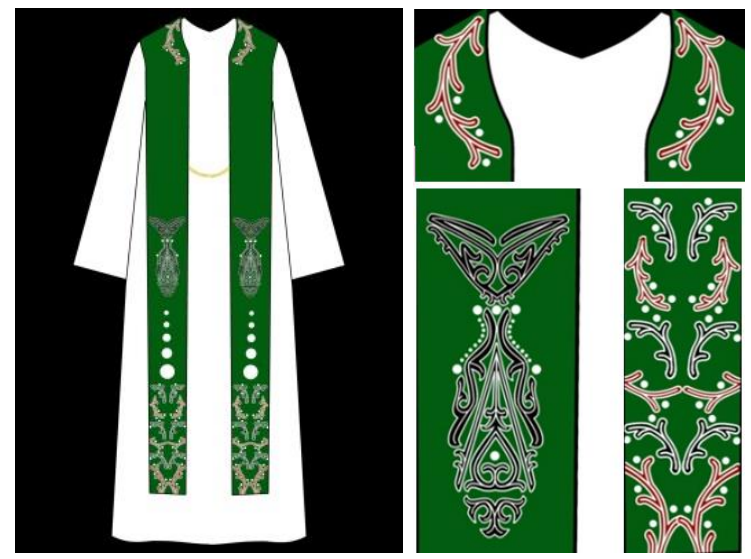

Gambar 29 : Desain stola hijau

Gambar 30 : Detail desain stola hijau

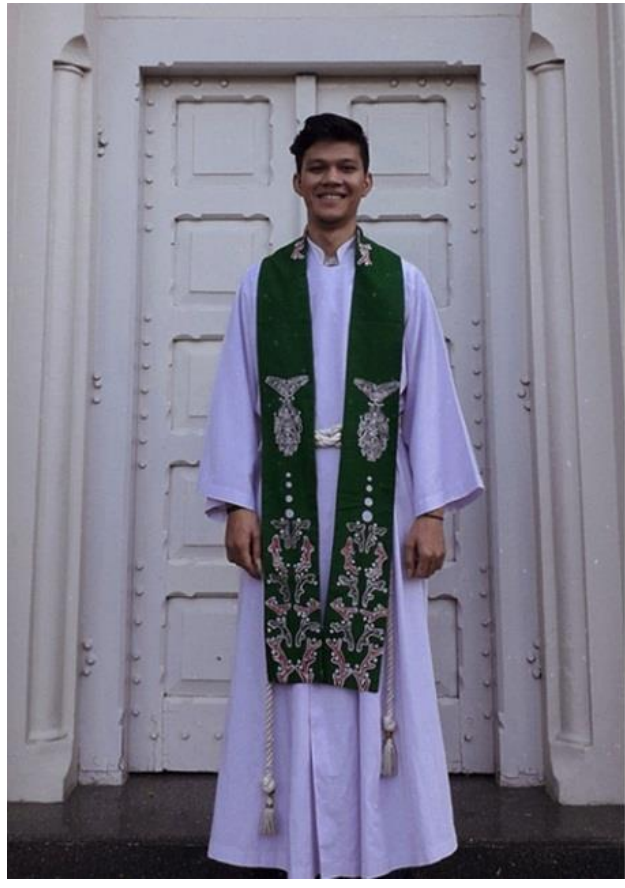

Gambar 31 : Foto produk stola hijau

Foto: Hardianti Veronika Rajagukguk 2019

Desain ini distrukturkan dari simbol ikan dan patahan ranting sebagai motif hiasannya. Makna simbolik dari ikan dijadikan sebagai lambang Kristus yang berarti penyelamat, karena pada jaman dahulu dipercaya bahwa ikan adalah hewan yang dapat menjauhkan dari kejahatan. Ukuran desain $120 \mathrm{~cm} \times 18 \mathrm{~cm}$.

\section{Desain Kasula Ungu}

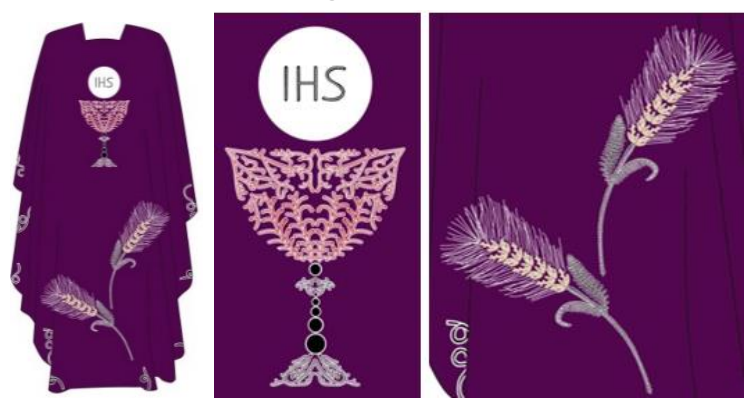

Gambar 32 : Desain kasula ungu bagian depan Gambar 33 : Detail desain kasula ungu bagian depan 


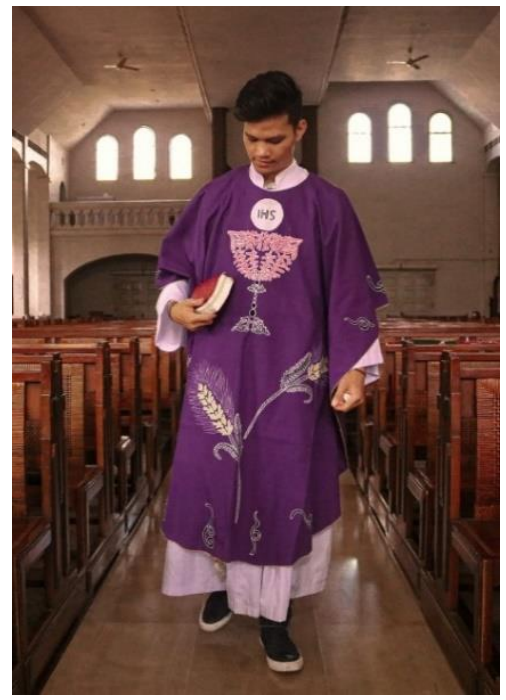

Gambar 34 : Foto produk kasula ungu bagian depan Foto: Hardianti Veronika Rajagukguk 2019

Desain ini distrukturkan dari hosti dan piala sebagai simbol utama dan simbol gandum. Roti dan anggur digunakan dalam perayaan Ekaristi atau Perjamuan Kudus yang menyimbolkan persekutuan dengan tubuh dan darah Kristus. Dahulu pembuatan roti menggunakan gandum sebagai bahan pokok, pembuatan anggur juga membutuhkan anggur. Dua bahan tersebut adalah 2 bahan persembahan bagi umat Kristen yaitu roti dan anggur yang menunjukkan dua hasil bumi yang menjadi bahan Ekaristi. Ukuran desain $170 \mathrm{~cm} x$ $120 \mathrm{~cm}$.

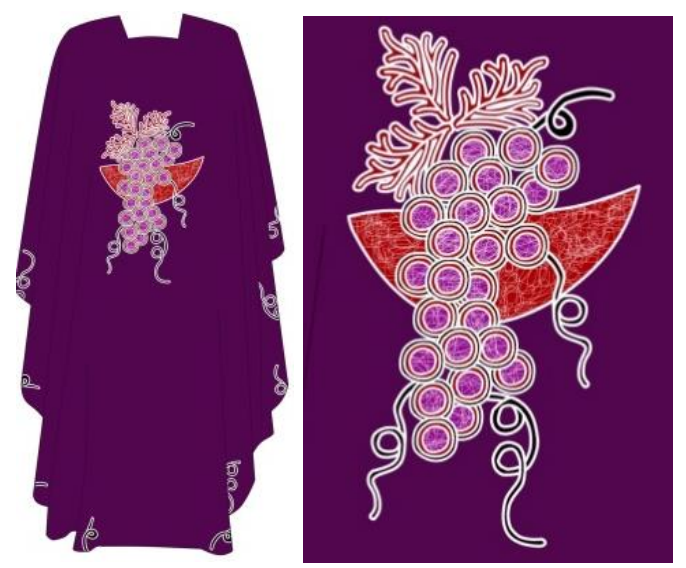

Gambar 35 : Desain kasula ungu bagian belakang Gambar 36 : Detail desain kasula ungu bagian belakang

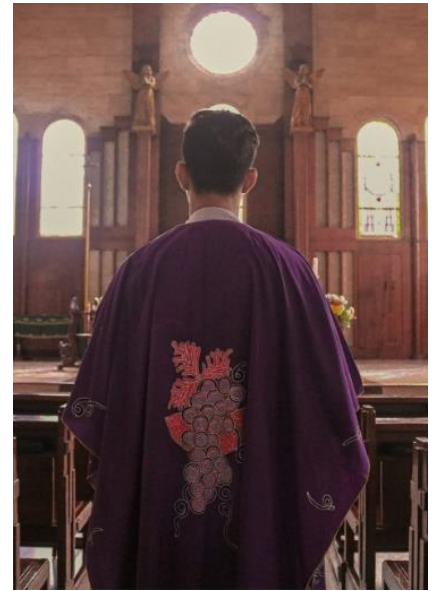

Gambar 37 : Foto produk kasula ungu bagian belakang Foto: Hardianti Veronika Rajagukguk 2019

Desain ini distrukturkan dari anggur di dalam wadah sebagai simbol utama. Roti dan anggur digunakan dalam perayaan Ekaristi atau Perjamuan Kudus yang menyimbolkan persekutuan dengan tubuh dan darah Kristus. Ukuran desain $180 \mathrm{~cm} \times 120 \mathrm{~cm}$.

\section{Desain Stola Ungu}

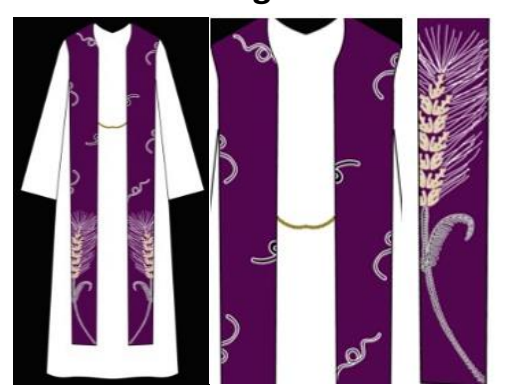

Gambar 38 : Desain stola ungu Gambar 39 : Detail desain stola ungu

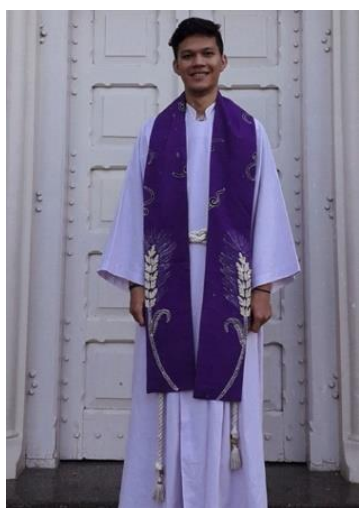

Gambar 40 : Foto produk stola ungu Foto: Hardianti Veronika Rajagukguk 2019 
Desain ini distrukturkan dari gandum sebagai simbol utama dan cabang menjuntai dari anggur sebagai motif penghias. Roti digunakan dalam perayaan Ekaristi atau Perjamuan Kudus yang menyimbolkan persekutuan dengan tubuh. Dahulu pembuatan roti menggunakan gandum sebagai bahan pokok, bahan tersebut adalah persembahan bagi umat Kristen sebagai hasil bumi yang menjadi bahan Ekaristi. Ukuran desain $120 \mathrm{~cm} x$ $18 \mathrm{~cm}$.

\section{PENUTUP}

Berikut akan dijelaskan serangkaian tahapan untuk menjawab pertanyaan diatas yang dapat disimpulkan sebagai berikut:

Pemilihan simbol-simbol disesuaikan dengan arti dari warna-warna liturgi setiap masanya. Seperti warna putih/kuning (makna kehidupan baru, dipakai saat Masa Paskah, Natal, perayaan-perayaan Tuhan Yesus (kecuali peringatan sengsara-Nya), serta peringatan Santa dan Santo pelindung), merah (makna api dan darah, dipakai saat hari Minggu Palma, Jumat Agung, Minggu Pentakosta, perayaan Sengsara Tuhan, pesta para rasul dan pengarang Injil (kecuali Yohanes), serta perayaan para martir), hijau (tenang, menyegarkan, melegakan, dan manusiawi, dipakai saat Masa Biasa sepanjang tahun), dan ungu (simbol kebijaksanaan, keseimbangan, sikap berhati-hati, dan mawas diri, digunakan saat masa Adven dan Prapaskah). Simbol-simbol yang biaasanya menghiasi pakaian liturgi adalah roti dan anggur, gandum, alpa dan omega, ikan, $X P, I H S$, lilin, anak domba, piala anggur, dan lainlain, yang berasal dari kitab suci.

Ide perancangan yang dipilih berdasarkan studi lapangan yang telah dilakukan di Gereja Katolik Santo Antonius
Padua Tiga Dolok, Medan Sumatera Utara, bahwa penggambaran simbol yang terdapat pada kasula dan stola cenderung monoton. Perancangan ini berharap dapat mendukung upacara ekaristi dalam Gereja tersebut dengan menampilkan penggambaran simbol yang khas pada kasula dan stola, yaitu dengan penggambaran Gorga. Pemilihan ide ini akan lebih tepat dan satu konsep jika diterapkan di daerah setempat, karena hampir seluruhnya umat yang beribadah di Gereja tersebut merupakan suku Batak Toba yang bagi mereka tidak asing lagi tentang sebuah Gorga. Gorga Batak Toba memiliki khas penggambaran dengan 3 warna yang disebut tiga bolit yaitu hitam, merah, dan putih, serta memiliki 3 garis yang disebut dengan Gorga si tolu lili. Ciri khas tersebut yang telah diterapkan dalam perancangan simbol-simbol pada kasula dan stola.

Pemilihan bahan adalah salah satu unsur yang penting dilakukan serta dipertimbangkan dan disesuaikan dengan kondisi daerah setempat. Bahan yang digunakan dalam pembuatan kasula dan stola, pada umumnya menggunakan bahan sutra yang dapat menampilkan kesan mewah serta mahal dari sebuah pakaian liturgi. Perancangan kasula dan stola dalam proyek ini menggunakan katun Bercolin sebagai bahannya. Katun Bercolin merupakan salah satu jenis kain yang tidak terlalu panas, serta dapat menyerap keringat dengan maksimal ketika digunakan. Pemilihan kain katun Bercolin diharapkan dapat menampilkan kesan sederhana seperti Yesus yang berpenampilan sederhana.

Pemilihan teknik batik tulis dapat menghasilkan inovasi baru dan berguna, serta diharapkan memperkenalkan teknik batik tulis kepada warga sekitar, khususnya umat Gereja 
Katolik Santo Antonius Padua Tiga Dolok. Proses Pembuatan proyek ini dilakukan di Batik Setya di Kampung Batik, Laweyan. Pemilihan warna dibuat berdasarkan warna-warna liturgi dalam Gereja Katolik yaitu kuning/putih, merah, hijau, dan ungu dengan menggunakan zat pewarna sintetis remasol.

Proyek Tugas Akhir ini menghasilkan 8 desain yang terdiri dari 4 desain kasula dan 4 desain stola. Ukuran desain dalam pembuatan proyek ini yaitu untuk kasula $170 \mathrm{~cm} \times 120 \mathrm{~cm}$ (sisi bagian depan), $180 \mathrm{~cm} \times 120 \mathrm{~cm}$ (sisi bagian belakang) sedangkan stola $120 \mathrm{~cm} \times 18 \mathrm{~cm}$. Perancangan proyek ini diharapkan dapat memberikan inovasi baru terhadap sebuah pakaian liturgi khususnya kasula dan stola, yang merupakan salah satu perlengkapan dalam Gereja Katolik yang biasa digunakan oleh Imam/Pastor dalam perayaan ekaristi.

\section{DAFTAR PUSTAKA}

Lukefahr, O. \& Shakti, V. P. 2014. Mengungkap Misteri dan Rahasia Misa Katoilik: Luman Deo

Ramadhan, I. 2013. Cerita Batik. Tangerang Selatan: Literati

Rizali, N. 2006. Tinjauan Desain Tekstil. Surakarta: UNS Press

Rizali, N. 2012. Metode Perancangan Tekstil. Surakarta: UNS Press
Windhu, I. Marsana. Bina Iman Liturgi 4 Mengenal Peralatan, Warna, dan Pakaian Liturgi: KANISIUS

Yudhoyono, A. B. 2013. Batikku Pengabdian Cinta Tak Berkata. Jakarta: PT. Gramedia Pustaka Utama

\section{Sumber Lain :}

Panggabean, S. \& Lestari, F. D. 2015. "Strategi Pemberdayaan Bahasa Lokal Demi Pelestarian Budaya Bangsa dan Upaya Penguatan Jati Diri", PROSIDING Seminar Nasional Bahasa Ibu Magister dan Doktor Linguistik Fakultas Sastra dan Budaya, Program Pascasarjana, Universitas Udayana

Siburian, T. P. 2017. "Makna Simbolik Ornamen Gorga Budaya Batak Toba", Skripsi, Fakultas Seni Rupa, Institut Seni Indonesia, Yogyakarta

Jurnal

Panjaitan, M.P. \& Sundawa, D. 2016. "Pelestarian Nilai-Nilai Civic Culture dalam Memperkuat Identitas Budaya Masyarakat: Makna Simbolik Ulos dalam Pelaksanaan Perkawinan Masyarakat batak Toba di Sitorang" dalam jurnal Corak : Jurnal Seni Kriya Vol. 3 No. 2 Oktober 2016.

Tampubolon. R. O. 2017. "Hohomion Na Tolu" dalam jurnal Corak : Jurnal Seni Kriya Vol. 10 No. 2 Oktober 